International Journal of Electrical and Power Engineering 12 (3-6): 26-31, 2018

ISSN: $1990-7958$

(C) Medwell Journals, 2018

\title{
Type-1 Fuzzy Logic Control System Based Maximum Power Point Tracking of Photovoltaic Systems
}

\author{
${ }^{1}$ Ammar Hussein Mutlag, ${ }^{2}$ Safaa Abdul Wahid Gadban and ${ }^{2}$ Rasha Khider Kareem \\ ${ }^{1}$ Department of Computer Engineering Techniques, \\ ${ }^{2}$ Department of Electrical Power Eengineering Techniques, Electrical Engineering Technical College, \\ Middle Technical University, Baghdad, Iraq
}

\begin{abstract}
Maximum Power Point Tracking (MPPT) controller is very important to improve the performance of the Photovoltaic (PV) system. Many algorithms have been introduced during the recent years. Two main factors are affected the Maximum output Power (MPP) obtained from a PV by a DC-DC converter which are irradiance (G) and Temperature (T). However, the most important point in the controller of PV systems is the design of the MPPT algorithm to maximize the extracted power from the PV system. Many reasons make the MPPT algorithms not sufficiently robust, these reasons are fast-changing environmental conditions, efficiency, accuracy at steady-state value and dynamics of the tracking algorithm. In this study, an intelligent controller based Type-1 Fuzzy Logic Controller (T1FLC) has been introduced to enhance the performance of the PV system. The T1FLC has been designed for PV system with capacity of $150 \mathrm{~W}$. The complete system has been modeled using MATLAB environment. The proposed T1FLC based MPPT method has been compared with Perturb and Observe ( $\mathrm{P} \& \mathrm{O})$ algorithm. The proposed T1FLC based MPPT method gives robust enhancement compare with $\mathrm{P} \& \mathrm{O}$ algorithm.
\end{abstract}

Key words:Fuzzy logic controller, maximum power point tracking, maximum power point, perturb and observe algorithm, photovoltaic, T1FLC

\section{INTRODUCTION}

Energy generation based on renewable energy resource has received a great attention. Photovoltaic (PV) system is one of the promising renewable energy technologies and it is considered as the core of Renewable Energy (RE) because it is available almost everywhere unlike wind, geothermal, sea waves, etc. photovoltaic system simply make electricity out of sunlight with no pollution and no depletion of materials (Subiyato et al., 2012). The PV generation system is clean and environmentally friendly source of energy. The renewable energy sources can be considered as an option for generating the clean energy where the electric energy has a negative effect such as pollution (Hammons et al., 2000). Photovoltaic (PV) power generation is a reliable and economical source of electricity that can be utilized in rural areas. The Photovoltaic (PV) energy that can get from solar radiation has received huge attention where it can consider one of the most promising renewable energy sources in the world (Akorede et al., 2010). The clean energy can be supplied by PV systems that have been developed to fulfill the energy demand which required by the modern society. However, the widespread utilization of PV systems has many challenges such as increasing the efficiency of energy conversion and ensuring the of power electronic converters (Lasseter et al., 2002). In addition to the advantage of photovoltaic there is a drawback of photovoltaic generation also has some weaknesses related to controllability and availability (Kottas et al., 2006). Extraction maximum power from PV system at every instant of time is important to overcome the problem of low energy conversion efficiency of PV modules in addition to get the maximum possible power. To overcome the problem of low efficiency to PV for achieving this, it must operate the PV systems closed to its Maximum Power Point (MPP). Maximum Power Point Tracking (MPPT) system plays an important role in operation of the PV system which it produces it is maximum power belong to the situation (Esram and Chapman, 2007). The maximum power when voltage or current is at the MPP of each characteristic curve. However, the MPP also changes with irradiation level and temperature due to the nonlinear characteristic of the PV

Corresponding Author: Ammar Hussein Mutlag, Department of Computer Engineering Techniques, Electrical Engineering Technical College, Middle Technical University, Baghdad, Iraq 


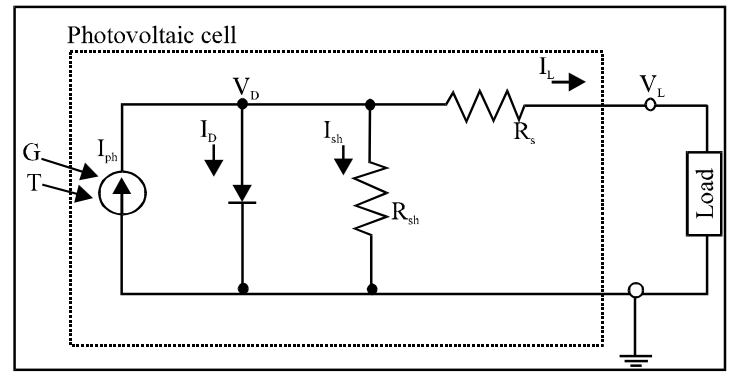

Fig. 1: Electrical equivalent circuit of a solar cell

module (Tey and Mekhilef, 2014). Recently, researchers started to develop MPPT algorithms to extract maximum power from PV system. The performance of the system depends on the operating conditions. Then, the maximum power extracted from the PV system depends on the weather conditions such as irradiance (G) and Temperature (T). Many MPPT algorithms have been mentioned in the literature. These algorithms have been classified into two groups. The first group is conventional methods such as Perturb and Observe (P\&O) (Ahmed and Salam, 2015), Hill Climbing (HC) and Incremental Conductance (IC) (Kjaer, 2012). The second group is soft computing methods such as Fuzzy Logic (FL) (Letting et al., 2012), Artificial Neural Network (ANN). Meanwhile, the other group is swarmed intelligence such as Particle Swarm Optimization (PSO) based MPPT and evolutionary algorithm such as Genetic Algorithm (GA) based MPPT.

This study introduced type-1 fuzzy logic control system to accurately track the maximum power point of $\mathrm{PV}$ system. To demonstrate the performance of the proposed method, the overall system has been modeled under the MATLAB environment.

Modelling and characterstic of PV system: The maximum extracted power from the PV system is depends on the environmental conditions. However, the $\mathrm{G}$ and $\mathrm{T}$ are the main conditions that are responsible for the performance of the PV system. The equivalent electrical circuit for a solar cell consists of a current source, series resistor $\mathrm{R}_{s}$ parallel-connected resistor $R_{s h}$ and a diode as shown in Fig. 1.

The mathematical model of the circuit which represents the output of the cell current (I) is expressed as (Houssamo et al., 2010):

$$
I=I_{\text {ph }}-I_{0}\left(e\left(\frac{V+I^{*} R_{s}}{n . k . T}\right)-1\right)-\frac{v+I^{*} R_{s}}{R_{\text {sh }}}
$$

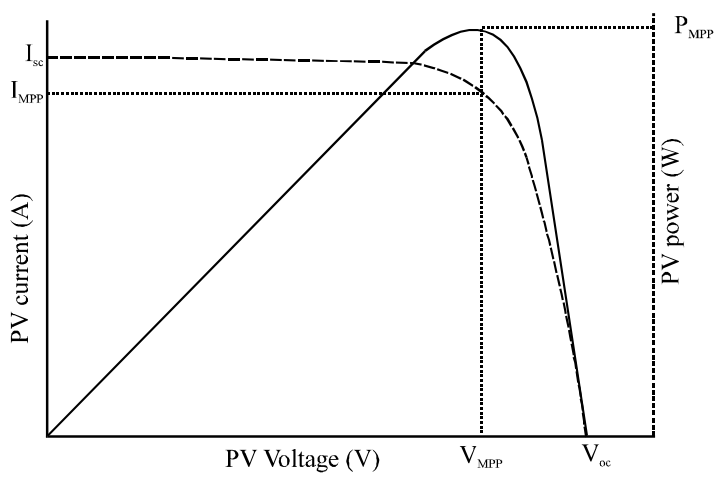

Fig. 2: Current-voltage and power-voltage characteristic curves of a solar cell

Table 1: Photovoltaic modules characteristics

\begin{tabular}{ll}
\hline PV module type: $M X-150 \mathrm{M}$ & Values \\
\hline Rated max power $\left(\mathrm{P}_{\mathrm{MAX}}\right)$ & $150 \mathrm{~W}$ \\
Voltage at $\left(\mathrm{P}_{\mathrm{MAX}}\right)\left(\mathrm{V}_{\mathrm{MPP}}\right)$ & $18.1 \mathrm{~V}$ \\
Current at $\mathrm{P}_{\mathrm{MAX}}\left(\mathrm{I}_{\mathrm{MPP}}\right)$ & $8.31 \mathrm{~A}$ \\
Open-circuit voltage $\left(\mathrm{V}_{\mathrm{oc}}\right)$ & $22.4 \mathrm{~V}$ \\
Short-circuit current $\left(\mathrm{I}_{\mathrm{sc}}\right)$ & $8.66 \mathrm{~A}$ \\
Current temperature coefficient $(\alpha)$ & $0.06 \mathrm{~A} / \mathrm{C}$ \\
Voltage temperature coefficient $(\beta)$ & $0.47 \mathrm{~V} / \mathrm{C}$ \\
\hline
\end{tabular}

Where:

$\mathrm{I}=\mathrm{APV}$ cell current $(\mathrm{A})$

$\mathrm{I}_{\mathrm{ph}}=\mathrm{A}$ photo current $(\mathrm{A})$

$\mathrm{I}_{0}=\mathrm{A}$ cell reverse saturation current $(\mathrm{A})$

$\mathrm{q}=$ An electronic charge $\left(1.6^{*} 10^{-19} \mathrm{C}\right)$

$\mathrm{V}=\mathrm{A}$ cell output Voltage $(\mathrm{V})$

$\mathrm{R}_{\mathrm{s}}=$ A series Resistance $(\pi)$

$\mathrm{n}=$ An ideality factor

$\mathrm{k}=$ A Boltzman's constant $\left(1.38^{*} 10^{-23} \mathrm{~J} / \mathrm{K}\right)$

$\mathrm{T}=\mathrm{A}$ cell Temperature $(\mathrm{K})$ and

$\mathrm{R}_{\mathrm{sh}}=$ A shunt resistance $(\pi)$

The maximum power point tracking can be finding utilize I from Eq. 1 which varies with $\mathrm{G}$ and $\mathrm{T}$. The same relationship can be used to find the MPPT in a PV module if the number of solar cells is known. The mathematical model can be utilized to determine the cell output current. The PV module characteristics are shown in Table 1.

The electric power can be obtained from product voltage and current. The curve of power-voltage characteristic for a solar cell can be gotten from a radiation level that is given as shown in Fig. 2. The power is equaled to zero at the maximum short-circuit current because the value of voltage is zero. Also, in case of open circuit point, the value of power is equaled zero. The maximum power point can be defined as a piratical point at which solar cell can deliver maximum power for a given radiation intensity. The output current that obtained from 
Eq. 1 depends on temperature and irradiation where this equation can be calculated the reference current $\left(I_{\text {MPP }}\right)$ that eventually gives maximum power point by the output voltage. The same relationship can be utilized to get maximum power point in $\mathrm{PV}$ module or a system in case of the number of PV is known. One of the drawbacks for this is the time-consuming and iterative process required to determine the cell output current that restrains using of the module in high-speed tracking. Generally, most of the MPPT algorithms usually start by sensing $I_{p v}$ and $V_{p v}$ from the PV system terminals. In order to extreme power from the PV framework, the procedure of the MPPT algorithm are implemented to find $V_{\text {MPP }}$ or $I_{M P P}$ where $P_{p v}$ is multiple of $\mathrm{I}_{\mathrm{MPP}}$ and $\mathrm{V}_{\mathrm{MPP}}$.

\section{MATERIALS AND METHODS}

Perturb and Observe (P\&O) method: The most commonly used MPPT algorithm is P\&O method. It is a popular MPPT method used to observe the change of power in the system. $P \& O$ depends on the applied step size for the current/voltage reference (Mutlag et al., 2016). The $\mathrm{P} \& O$ method utilize only one sensor, hence, it is easy to implement. In P\&O method, the PV current and voltage at sampling time ( $(t)$ is first measured and then the PV Power $(\mathrm{P}(\mathrm{t}))$ is calculated and compared with Previous sample $\mathrm{P}$ $(\mathrm{t}-1)$. If $\mathrm{P}(\mathrm{t})-\mathrm{P}(\mathrm{t}-1)>0$ that means the algorithm move toward the MPP. If $P(t)-P(t-1)<0$ that mean the algorithm is moving away from the MPP. Figure 3 shows the conventional P\&O method based MPPT of a PV system.

Type 1 Fuzzy Logic Control (T1FLC): Many advantages of using T1FLC in maximum power point tracing which are better performance, simple design and robust. Moreover, this technique does not require the knowledge of the exact model of the system. T1FLC systems components are fuzzifier, knowledge base, inference engine and defuzzifier as can be shown in Fig. 4.

The input of the T1FLC which they are $G$ and $T$, whereas the output is the $\left(I_{\text {MPP }}\right)$. The flowchart of the proposed T1FLC is shown in Fig. 5. The input variables $(\mathrm{G}),(\mathrm{T})$ are related in terms of several linguistic variables by using five triangle fuzzy subsets which are mean by NB (Negative Big), NS (Negative Small), Z (Zero), PS (Positive Small) and PB (Positive Big). The membership functions are shown in Fig. 6 and 7. The output variable is using five triangle fuzzy subsets. The membership functions are shown in Fig. 8.

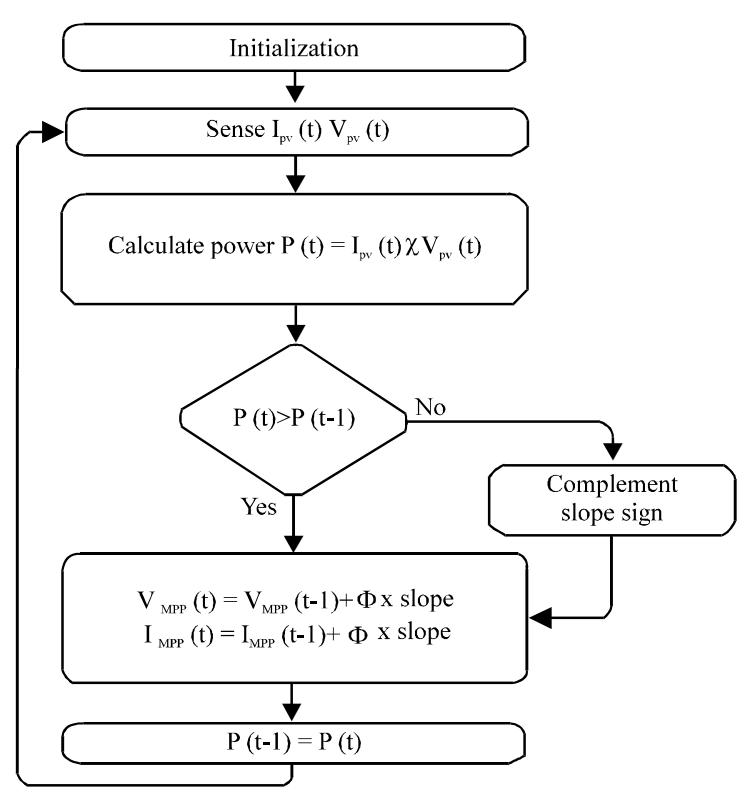

Fig. 3: The conventional P\&O method for MPPT of a PV system

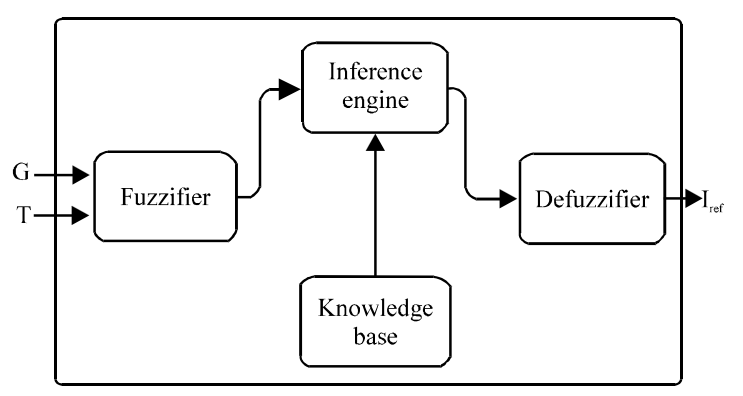

Fig. 4: Fuzzy logic controllers

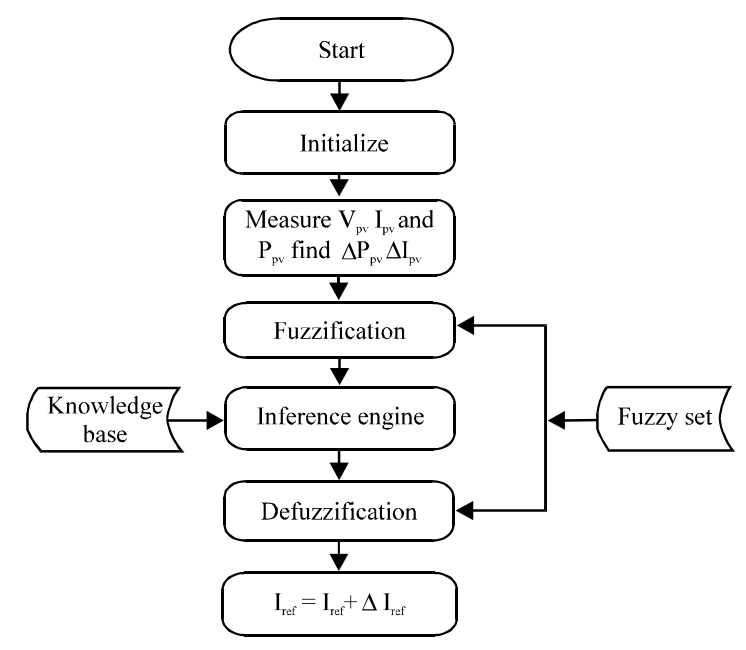

Fig. 5: Flowchart of a fuzzy logic control method 


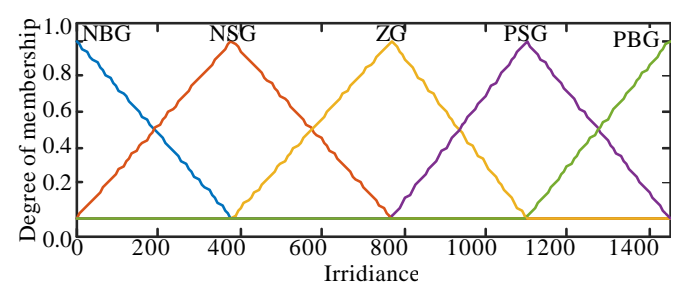

Fig. 6: Membership functions of irradiance $(\mathrm{G})$

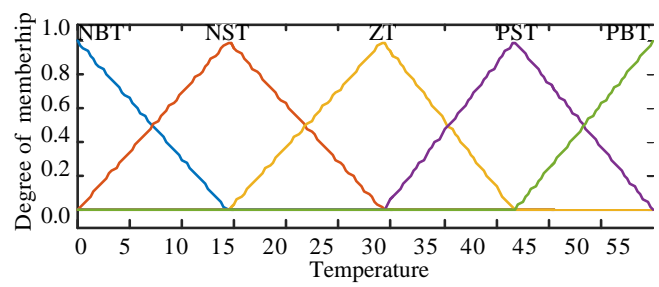

Fig. 7: Membership functions of Temperature (T)

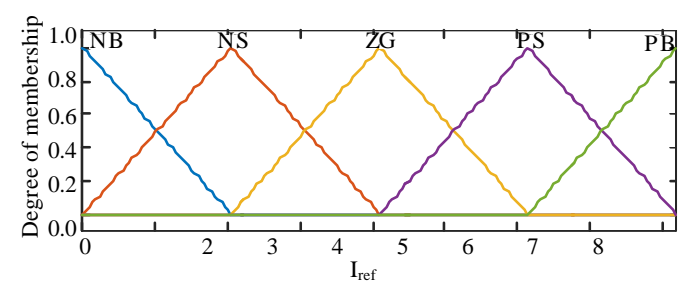

Fig. 8: Membership functions of output

\section{RESULTS AND DISCUSSION}

The response and performance of the proposed T1FLC based MPPT for $150 \mathrm{~W}$ PV system has been simulated utilizing MATLAB environment. The performance of the proposed T1FLC has been compared with the conventional $\mathrm{P} \& \mathrm{O}$ algorithm to exhibit its capability to track the MPP under nominal conditions for PV system. Figure 9 shows the speed response of the proposed T1FLC. The figure shows that the proposed T1FLC can track the $150 \mathrm{~W}$ powers and achieve very fast response compared with the $\mathrm{P} \& \mathrm{O}$ algorithm. This indicates that the performance of the PV system based T1FLC has been improved. The steady state response of the proposed T1FLC based MPPT is shown in Fig. 10. This figure shows that the response of the T1FLC is stable without any oscillation around the steady-state compares with the $\mathrm{P} \& \mathrm{O}$ algorithm. These results show a superior performance of the proposed T1FLC system.

Various irradiances with constant temperature were carried out for further evaluation. Figure 11 shows the ramp change of irradiance from $1000-950 \mathrm{~W} / \mathrm{m}^{2}$. The response of the ramp change is shown in Fig. 12. It shows

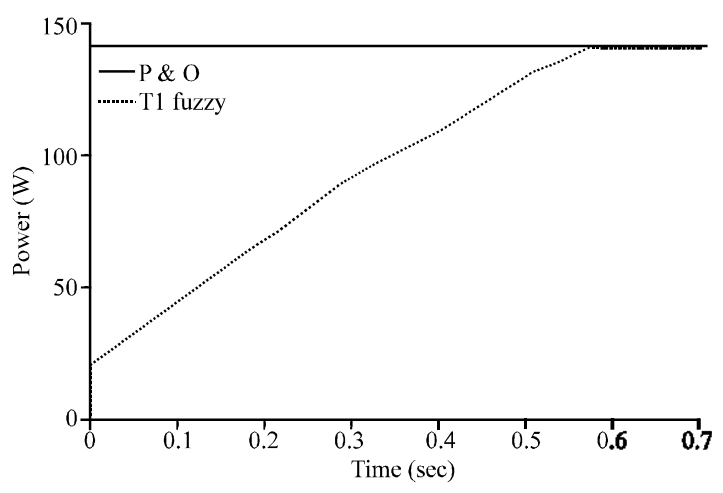

Fig. 9: Speed response of the T1FLC and conventional $\mathrm{P} \& \mathrm{O}$ algorithm

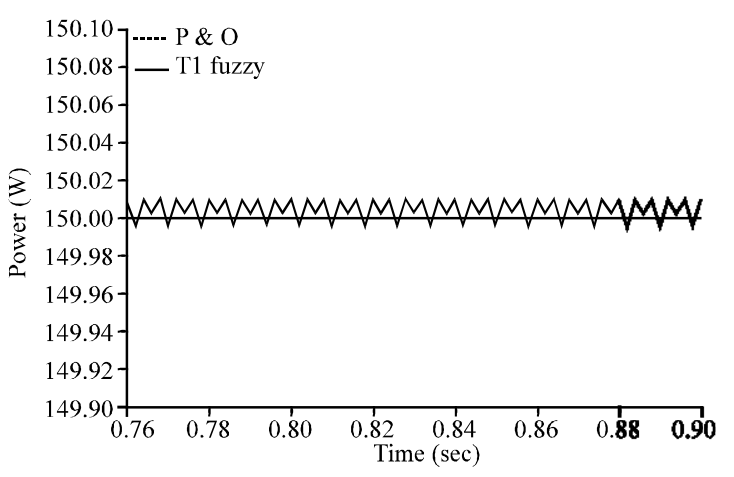

Fig. 10: Steady-state response of the T1FLC and the conventional $\mathrm{P} \& \mathrm{O}$

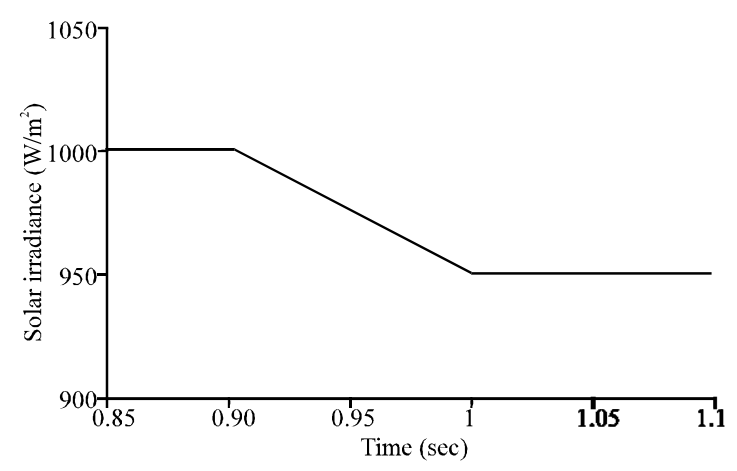

Fig. 11: Ramp irradiance change

that the T1FLC algorithm can extract more power compared with the Ps\&O algorithm. Furthermore, the proposed T1FLC shows a stable change compare with large oscillation using the conventional $\mathrm{P} \& \mathrm{O}$ algorithm during the ramp irradiance change.

Further evaluation using step change of irradiance from 1000 to $950 \mathrm{~W} / \mathrm{m}^{2}$ has been achieved as can be shown in Fig. 13. The response of the step irradiance change is shown in Fig. 10. This figure clearly shows that 


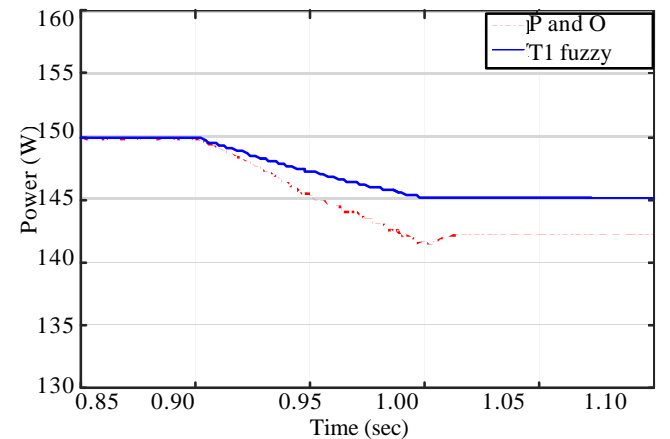

Fig. 12: Response of T1FLC and $\mathrm{P} \& \mathrm{O}$ for the ramp irradiance change

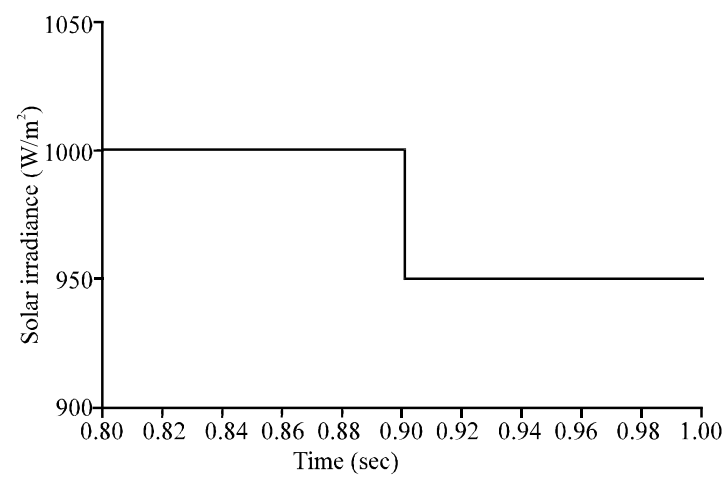

Fig. 13: Step irradiance change

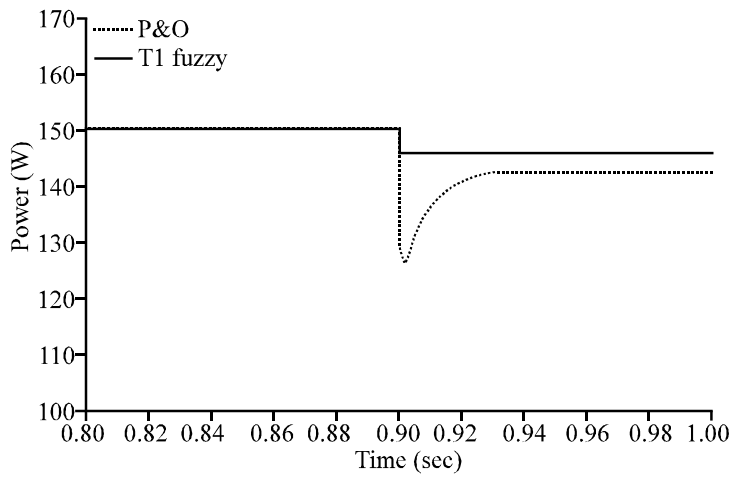

Fig. 14: Response of T1FLC for step irradiance change

the proposed T1FLC achieved very fast response compared with the conventional $\mathrm{P} \& \mathrm{O}$ algorithm. Furthermore, T1FLC achieved MPP with very small oscillation as shown in Fig. 14.

For further evaluation, various temperature changes have been achieved with constant irradiance. Figure 15 shows the ramp temperature change from $25-35^{\circ} \mathrm{C}$. The response of the ramping temperature change obtained by T1FLC and P\&O algorithm is shown in Fig. 16. In this

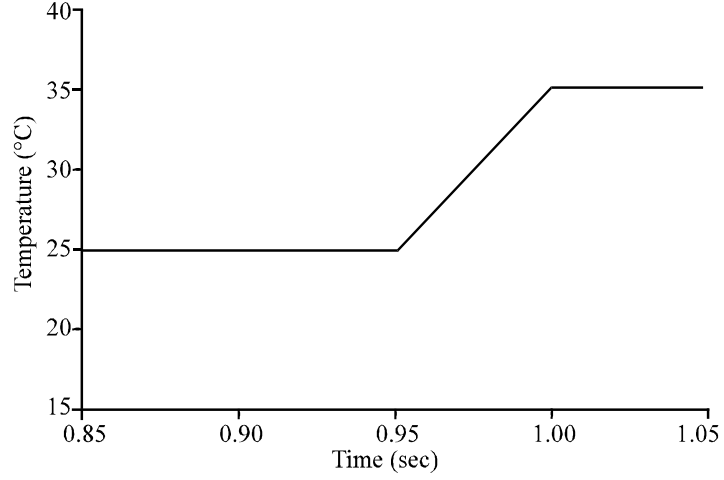

Fig. 15: Ramp temperature change

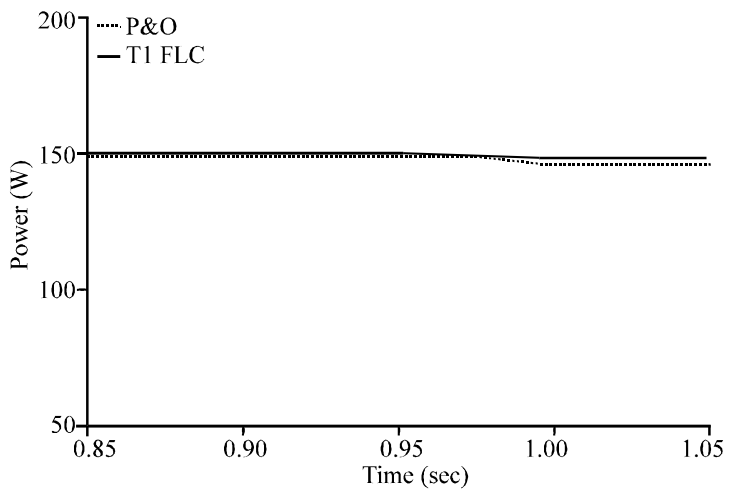

Fig. 16: Response of T1FLC and $\mathrm{P} \& \mathrm{O}$ for the ramp temperature change

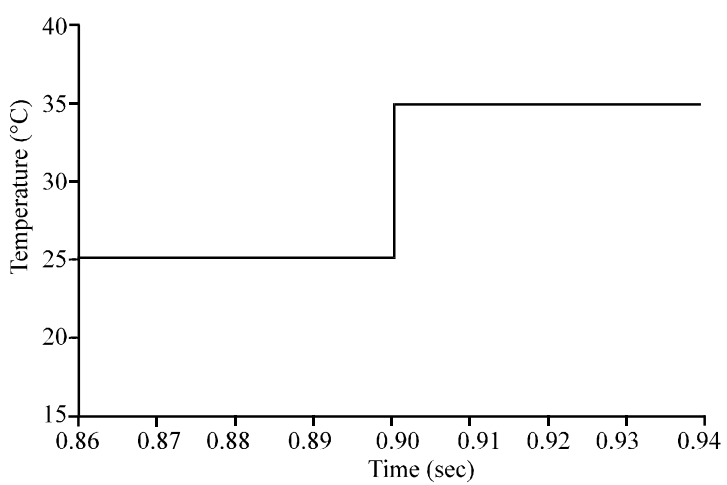

Fig. 17: Step temperature change

case, the proposed T1FLC shows high performance compare with $\mathrm{P} \& \mathrm{O}$ algorithm regarding fast and oscillation.

Another test of the proposed T1FLC has been carried out using step temperature change from $25-35^{\circ} \mathrm{C}$ with constant irradiance as can be shown in Fig. 17. Figure 18 shows that the response of the T1FLC is better 


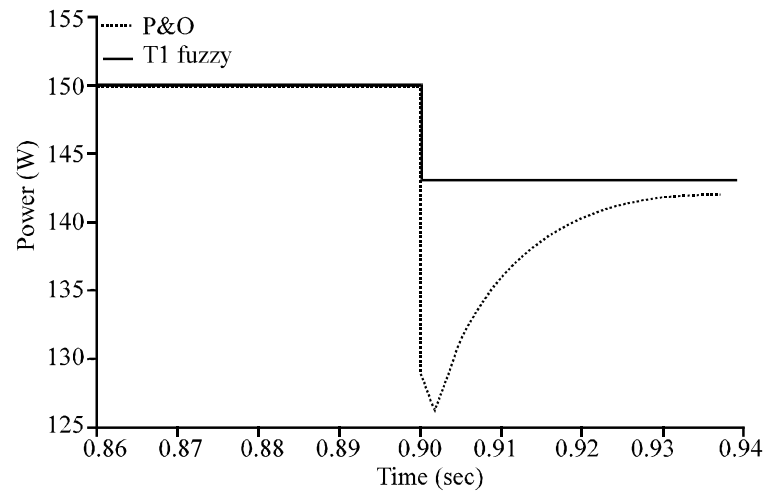

Fig. 18: Response of T1FLC and P\&O for the step temperature change

performance and can accurately track the MPP with short time and acceptable oscillation compared with the $\mathrm{P}$ and $\mathrm{O}$ algorithm. These results show the robustness of the proposed T1FLC compare with the $\mathrm{P} \& \mathrm{O}$ algorithm

\section{CONCLUSION}

Type-1 fuzzy logic control system based maximum power point tracking of photovoltaic systems has been proposed in this study. The performance of the T1FLC MPPT algorithm has been evaluated under various conditions and change in irradiance and temperature. Therefore, the PV and T1FLC based MPPT have been developed in MATLAB environment. The results indicate in all condition the T1FLC algorithm can achieve best performance compared with the conventional $\mathrm{P} \& \mathrm{O}$ algorithm. In additional, the T1FLC algorithm succeeds to track the maximum power point in all the test cases. Furthermore, the results indicate that the T1FLC Algorithm is more robust compared with sconventional $\mathrm{P} \& \mathrm{O}$ algorithm.

\section{REFERENCES}

Ahmed, J. and Z. Salam, 2015. An improved Perturb and Observe ( $\mathrm{P} \& \mathrm{O})$ Maximum Power Point Tracking (MPPT) algorithm for higher efficiency. Appl. Energy, 150: 97-108.
Akorede, M.F., H. Hizam and E. Pouresmaeil, 2010. Distributed energy resources and benefits to the environment. Renewable Sustainable Energy Rev., 14: 724-734.

Esram, T. and P.L. Chapman, 2007. Comparison of photovoltaic array maximum power point tracking techniques. IEEE Trans. Energy Convers., 22: 439-449.

Hammons, T.J., J.C. Boyer, S.R. Conners, M. Davies and M. Ellis et al., 2000. Renewable energy alternatives for developed countries. IEEE. Trans. Energy Convers., 15: 481-493.

Houssamo, I., F. Locment and M. Sechilariu, 2010. Maximum power tracking for photovoltaic power system: Development and experimental comparison of two algorithms. Renewable Energy, 35: 2381-2387.

Kjaer, S.B., 2012. Evaluation of the hill climbing and the incremental conductance maximum power point trackers for photovoltaic power systems. IEEE. Trans. Energy Conversion, 27: 922-929.

Kottas, T.L., Y.S. Boutalis and A.D. Karlis, 2006. New maximum power point tracker for $\mathrm{PV}$ arrays using fuzzy controller in close cooperation with fuzzy cognitive networks. IEEE. Trans. Energy Convers., 21: 793-803.

Lasseter, R., A. Akhil, C. Marnay, J. Stephens and J. Dagle et al., 2002. Integration of distributed energy resources: The CERTS microgrid concept. Master Thesis, California Digital Library, University of California, ?Oakland, California?.

Letting, L.K., J.L. Munda and Y. Hamam, 2012. Optimization of a fuzzy logic controller for PV grid inverter control using S-function based PSO. Solar Energy, 86: 1689-1700.

Mutlag, A.H., A. Mohamed and H. Shareef, 2016. An improved perturbation and observation based maximum power point tracking method for photovoltaic systems. J. Teknol., 78: 19-25.

Subiyanto, A. Mohamed and H. Shareef, 2012. Hopfield neural network optimized fuzzy logic controller for maximum power point tracking in a photovoltaic system. Intl. J. Photoenergy, 2012: 1-13.

Tey, K.S. and S. Mekhilef, 2014. Modified incremental conductance MPPT algorithm to mitigate inaccurate responses under fast-changing solar irradiation level. Solar Energy, 101: 333-342. 